Portland State University

PDXScholar

2015

\title{
A Musical Interpretation of the Past : America is in the Heart by Carlos Bulosan Re-told through the Craft of Folk Songs
}

Haley H. Heynderickx

Portland State University

Follow this and additional works at: https://pdxscholar.library.pdx.edu/honorstheses

Let us know how access to this document benefits you.

Recommended Citation

Heynderickx, Haley H., "A Musical Interpretation of the Past : America is in the Heart by Carlos Bulosan Re-told through the Craft of Folk Songs" (2015). University Honors Theses. Paper 168.

https://doi.org/10.15760/honors.179

This Thesis is brought to you for free and open access. It has been accepted for inclusion in University Honors Theses by an authorized administrator of PDXScholar. Please contact us if we can make this document more accessible: pdxscholar@pdx.edu. 
A Musical Interpretation of the Past: America is in the Heart by Carlos Bulosan Re-told through the Craft of Folk Songs

By

Haley H. Heynderickx

An undergraduate honors creative thesis submitted in partial fulfillment of the requirements for

\author{
the degree of \\ Bachelor of Arts \\ in \\ University Honors \\ and \\ Communication Studies
}

Thesis Advisor

Dr. Marie Lo 


\section{Table of Contents}

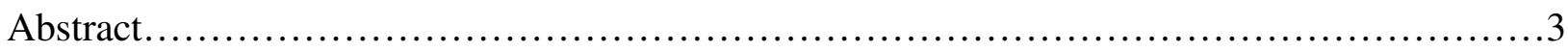

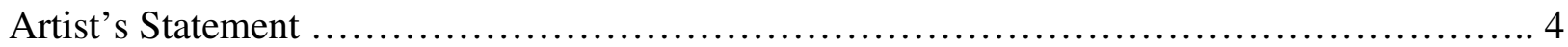

Asian American Voice in Civil Rights and Studies......................................6

America is in the Heart by Carlos Bulosan.................................................11

Qualifications of Researcher................................................... 13

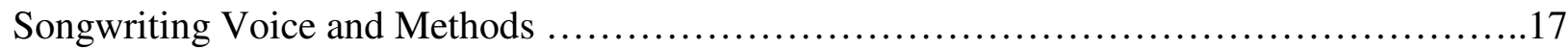

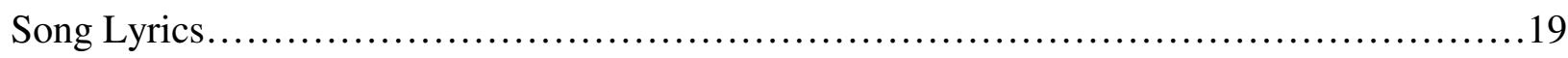

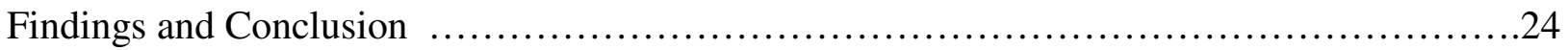

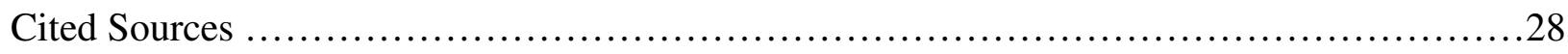




\begin{abstract}
Songwriting is an art in which lessons and experiences of the past and present can be communicated through the channel of music and writing. From this mode of communication, this creative project embodies a different take on the incorporation of "voice" by analyzing a significant work of Filipino American literature to be further experienced by the general public in song. In this project I aimed to create three relatable songs for future listeners by incorporating themes from the novel, America is in the Heart by Carlos Bulosan. As a Filipino immigrant, poet and activist during the Great Depression, Bulosan's journey symbolizes prominent themes of individuality, silence, and farewell which are deeply relatable to listeners from all walks of life. Through the use of found poetry, themes were found and then interpreted into folk songs. This project required that I balance three separate roles: researcher, folk musician, and identification as a Filipino American in order to acquire themes relatable to the human experience, choosing the right lyrics through found poetry, and relay these emotions through music in a relatable way towards listeners. Since this novel provides a significant contribution towards Asian American literature, this paper gives a brief history of the novel, along with how Asian American literature came to fruition in university curriculums. Qualifications of the investigator are explored, along with the songwriting process that composed these themes and balance. These songs were recorded through "Tiny House Records," and will be shared further through a presentation with PCHRP, Portland's Committee for Human Rights in the Philippines, in July 2015.
\end{abstract}




\section{Artist's Statement}

Being born mixed race with a mother of Filipino descent, my inquiring mind expanded after enrolling in an Asian American literature class. Having not known many intimate histories of Chinese, Japanese, Vietnamese and Filipino American experiences, a spark of human curiosity flashed between my eyes, following a period of confusion how such intimate perspectives over the past 150 years had never been relayed or shared to me earlier on. Almost all perspectives I had come across in this class were ones I had not yet heard during my years of public education. Being a musician, I also began to wonder if there was a way to relay their stories through song.

I found an intense interest in Asian American literature through this class, and immediately wanted to combine my thesis with my newfound emotions. For in learning these histories, I reached a new appreciation towards the struggle of immigrant assimilation, the quest towards individuality, and the intimate silence of being a stranger from a different land. The class also affected me on a deeply personal level as I began finding a new understanding of my mixed race identity. I slowly started to brainstorm ways of how to relay these concepts with my friends, family, and community, but I soon realized how difficult it was to have these ideas stick when shared.

Living in a generation of new media, we are bombarded by new information every day. How can one focus so intently on the past with all of this new information flowing towards us? I saw these works of literature as important because they reflect important lessons that can help future generations further understand how to get along in a progressively changing $21^{\text {st }}$ century, while also giving recognition and respect to those who went through such experiences. As my passion for Asian American literature grew, so did my intent on wanting to share it. Then the 
question came to mind: Is there another way to relate themes in Asian American literature to a larger public? How can I share these stories in a new engaging form?

Being a communication major, I see the value in emotional appeal when creating a message, and I decided to challenge these questions with my greatest passion and hobby outside of school: songwriting. Having played guitar for over ten years, and being an active folk songwriter for the last of these two, I decided to communicate themes that are not commonly relayed through music by analyzing a work of Filipino American literature, Carlos Bulosan's America is in the Heart. Seeing this creative project as a chance to better understand this work of literature and abundance of human experience, I took this experience as an opportunity to combine my skills and curiosities with literature in order to re-tell the past in a way that can be easily consumed by the passerby; or at least spark their interest.

It didn't take long for me to realize how embodying the entire field of Asian American Literature through song was close to impossible, as there is already much generated controversy as to what defines "Asian American Literature." What if an author is not of Asian origin, but writes about an Asian American experience? What if the author is Asian American and writes a body of work not involving Asian American experiences? These are merely questions from the tip of the iceberg. However, they did encourage me to start at the micro level, and really dissect a subject I could wrap my mind around.

Being half Filipino, I decided to represent a novel of great importance to the Filipino American community, the autobiographical novel America is in the Heart by Carlos Bulosan, which was written during the Great Depression and published in 1943. His writings as a Filipino immigrant embodied the early, arguably one of the most difficult economic times to arrive in America. I closely analyzed and interpreted his writing to find three major themes, in which I 
embodied through folk songs. To give background on how these songs came into actualization, this paper aims to weave the metaphor of "voice" by first analyzing the historical background in which Asian American literature came into existence through the civil rights movement of the 60s and 70s. Then, the "voice" in relaying Bulosan's experience will be textually analyzed through interlacing his narrative with the Filipino experience during the 1930's and 40's. Following will be an investigation of folk songwriting as a mode of communication. This section will also include my role as a musician and researcher, the lyrics of the songs, along with findings of the experience as a whole. After finishing my research and writing, I have produced three songs between balancing the roles of active researcher, engaged Filipino American and musician. In these three songs I have captured three significant themes that are both crucial to understanding Bulosan's experiences, but also to the listener in realizing their own histories of experience.

This creative project is about voice, identity, and cultural stigmas as represented in song. Through the form of music, this project became a reincarnation of voice itself, representing the different modes of communication in which songs can go through in order to be heard and to develop a new understanding of one's identity. 


\section{Asian American Voice in Civil Rights and Studies}

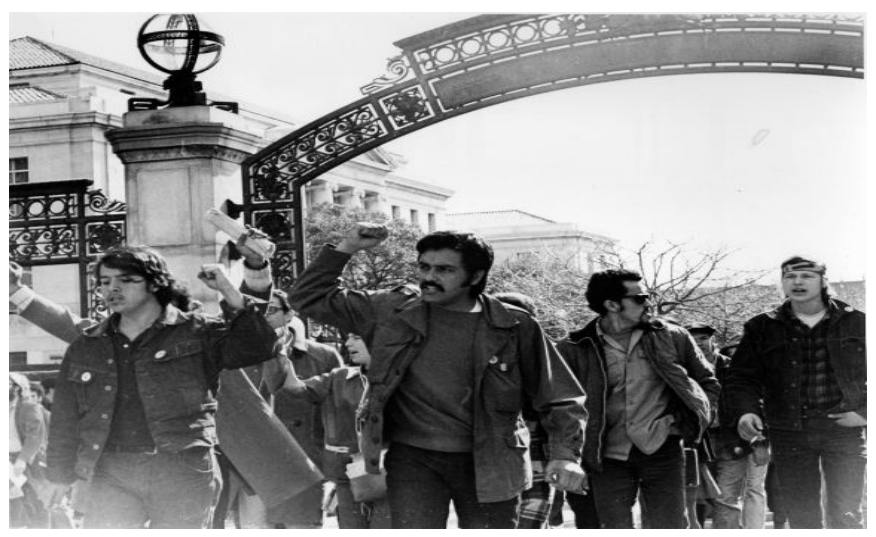

(Third World Liberation Front, San Francisco State University, 1969)

"The very birth of the term Asian American came from a rejection of white supremacy, institutional racism and in full support of Black Power. We stood together. Some of us still stand together. We must stand together again. Asian American identity was originally meant to be a way to identify with each other and to share our experiences to identify with the struggles of others, whether it was African Americans or Asians overseas, and it was less a marker of what one was and more a marker of what one believed. That it has now become synonymous with 'pride in one's ethnic heritage' is a complete evisceration of what it was originally, and what it was meant to be."

---Chris Ijima in (name source)

Asian American literature is a powerful lens in which histories of different cultural experiences can teach us how we may all get along in the twenty-first century. It offers the stories and personal tales of those who have lived through something that cannot be simply captured in an image or a listing of statistics. Understanding is found on a fundamental level by diving into their minds and personal perspectives. So much of history is seen through a Eurocentric lens. However with the Asian American perspective we enter an opportunity to revision what our world could be like with the inclusivity these authors dreamed and strived for. 
Also, in the re-telling of these stories, the authors and their descendants are contributing to the larger meaning of what it means for us to be considered "American."

It was not until the late 1960s that the heart of Asian American Studies came to light. This was a result of strikes by the Third Liberation Front, a group of students of color at University of California, Berkeley and San Francisco State University. They demanded their college experience include the histories of African Americans, Asian Americans, Chicanos and Native Americans. Their reasoning was grounded on the belief that racially marginalized groups were not represented equally, or at all, in the existing disciplines colleges at the time had to offer.

With the work of the Third World Movement, the Civil Rights Era was able to bring attention to various American ethnic minorities through a protest at San Francisco State which had slowly became the longest student strike in US history. Having primarily African Americans begin the rally between ethnic groups at San Francisco state, so began the empowerment of Asian Americans and many others into this protest against a dominant white society.

The momentum only furthered in the years to come, as the 1970's welcomed Asian American Studies into an era of self-discovery. Though programs were slimmed down in 1973 due to economic crisis, UCLA was the first university to devote a journal based on research of Asian Americans. They also published Roots: An Asian American Reader which in turn was used as a primary textbook in the 1970's introductory Asian American Studies courses around the country. With the spreading of Ethnic Studies courses and departments across the states, Asian American Literature began its form in colleges, presenting and highlighting stories by authors who had yet to be heard, and the 70s provided to be a time of its largest growth. The amount of Asian American anthologies began pouring in such as David Hsin-FU Wand's Asian American Heritage: An Anthology of Prose and Poetry and Aiiieee! An Anthology of Asian-American 
Writers. These anthologies shed light on many arising literary scholars and writers, highlighting a vast number of perspectives from the $20^{\text {th }}$ century.

It is difficult in having an entire body of literature represent groups of South, East, and Southeast Asian countries which in their own individual existence are so complex and unique. There is hope that in the future, this group of study can perhaps be further narrowed to examples such as "Chinese American Studies," or "Filipino American Studies," as each body of literature is attuned to each culture. However, there has been a consistent thread that links people from these countries together in the way they have been seen throughout history, becoming seen as a group of "model minorities." There has been much speculation of how this stereotype came to existence, but most ethnic studies researchers believe this is due to African America's being primarily seen as second class citizens due to their deep rooted history in America, while Asians have been primarily seen as something "other," "alien" or "outsider." Understanding this history is valuable in linking Asian American identity in the present day, as it furthers our awareness of these stereotypes while simultaneously promotes an inclusive consciousness of backgrounds and cultures.

"White" in the late nineteenth and early twentieth century also meant citizenship, which is why many immigrants of Asian ancestry attempted to define themselves as "white" in order to naturalize and gain the rights to citizenship. Having historical evidence to why these stereotypes of the model minority came into play is very important in understanding where these literary themes in Asian American Literature often stem from; as remembering this history is the beginning is the understanding of the transformation of "voice" through each distinct novel. Though the Asian American experience is a compilation of many different Asian countries, the reoccurring theme that grows through this body of literature is the emerging voice; whether it be 
from first generation immigrants or second, or third. Though each plotline is distinct to each author's individual story, the transition of "voice" is a very important aspect of Asian American culture, as it represents the overcoming of stigma and the emergence of individuality.

And now we return to where this creative project stands today. Taking a piece of this Asian American literature puzzle, this thesis aims to shed light on a distinct culture in which the emergence of individuality remains present: the moving life story of Carlos Bulosan. With his arrival to the states taking place during the Great Depression, he battled many social inequalities and economic barriers in his attempts to achieve the American dream. However, his experience became distinct in the Asian American community as he was able to find great hope despite his hardships through his growth as a writer and activist representing Filipino American farm workers. He found his voice and he used it proudly to represent his people. 


\section{America is in the Heart}

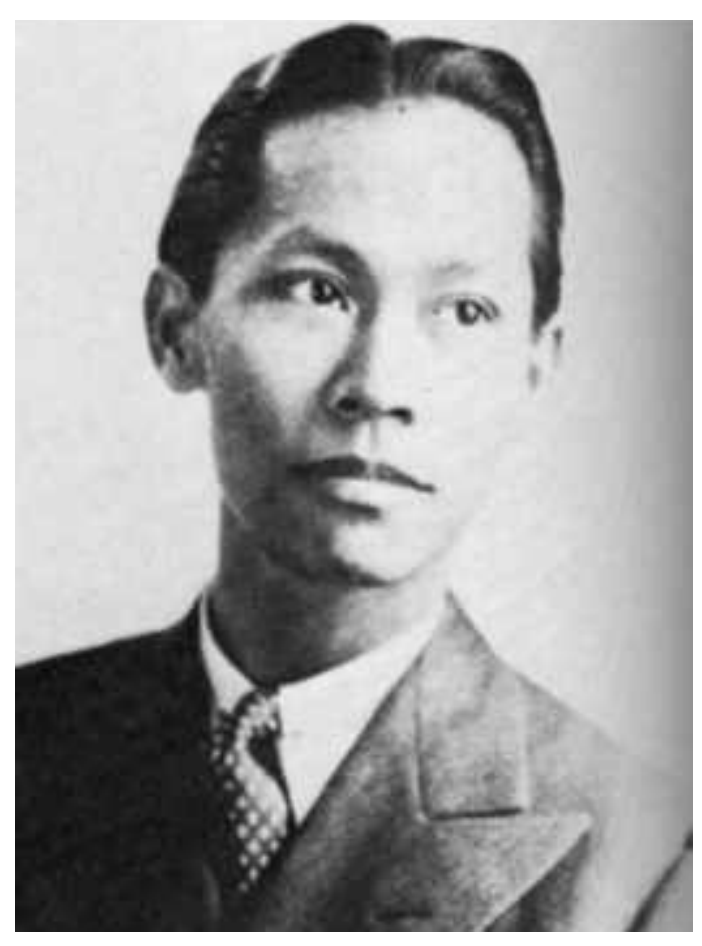

"We are all Americans that have toiled and suffered and known oppression and defeat, from the first Indian that offered peace in Manhattan to the last Filipino pea pickers. America is not bound by geographical latitudes.

America is not merely a land or an institution. America is in the hearts of men that died for freedom; it is also in the eyes of men that are building a new world... America is also the nameless foreigner, the homeless refugee, the hungry boy begging for a job and the black body dangling on a tree. America is the illiterate immigrant who is ashamed that the world of books and intellectual opportunities is closed to him. We are all that nameless foreigner, that homeless refugee, that hungry boy, that illiterate immigrant and that lynched black body. All of us, from the first Adams to the last Filipino, native born or alien, educated or illiterate- We are America!” (Bulosan, 1946, p. 189).

The Filipino American experience is a unique one in that the Philippines from the late 1890s until the 1940s was considered “America's Little Brother” proceeding the Spanish-American War. Many Filipino immigrants came to the United States expecting to be treated as equals to their white American peers, only to be immobilized by the Great Depression, scarce labor 
intensive job opportunities, and lack of any official citizen rights. Filipinos were seen as the sojourner, not the settler (Takaki, 1989).

Carlos Bulosan was one among these immigrants, hoping to start a new life in America at the young age of seventeen due to harsh living conditions in the Philippines. Born November 24th, 1913, in Mangusmana, Bulosan began his boyhood in a poverty stricken area of Luzon, Binalonan region. Raised into a family of farmers, Bulosan spent most of his youth working on fields with his father, or selling produce in the market with his mother in order to pay for his older brother's schooling. He damaged his health at a young age, having to climb tall coconut trees in hopes of gaining extra income for his family, only to endure distressing lung problems from falling. He lived with a limp from a broken leg that never healed properly, along with breaking several ribs.

This, unfortunately, was only the beginning of Bulosan's intense struggles during his migration to America, as he was greeted by an uncomfortable loneliness as he navigated lack of work, racism, harsh living conditions, labor strikes, police brutality and fleeting companionship during America’s 1930s. During the Depression, Filipino immigrants (around 45,200 total) worked mainly in domestic service, fisheries of the Northwest and Alaska, and Agriculture. Of these workers, $25 \%$ worked in the service industry in 1930, $9 \%$ on Alaska salmon fisheries, and 60\% in agriculture, mainly involving asparagus farms (Takaki, 1989, p. 322). In his first several days in the United States, Bulosan was quickly shipped to Alaska, where he was swindled out of his money despite months of hard work, slowly realizing the trail of racial inequalities and income disparity amongst his fellow workers. His memoir is an intense historical reminder of what experiences were like as a Filipino on the West Coast, hopping periodically from train to train through Lompoc, Stockton, Portland, and many other rural West areas. In these travels, he 
witnessed intense prejudices and slowly took part in writing for justice and later started a Filipino Labor Union which reflected a greater changing consciousness at the time to fight back against such injustices.

His writings track a life of fleeing towns, making friends with workers in the "Little Manilas" across California, Oregon and Washington as he worked field to field as the seasons alternated. In 1934, around the time Bulosan arrived to the states, the Tydings McDuffie Act was put into law, promoting Filipino exclusion due to conflicts with white labor. This law limited a miniscule amount of Filipinos into America, a mere 50 immigrants (Takaki, 1989, p. 331). This time period provides significant context to Bulosan's experience, as this was a time of intensified racial tension throughout the states, and worsened living conditions amongst the arrived Filipinos. Through his journey, his health progressed to a detrimental state, being diagnosed with tuberculosis, forcing him to be bed ridden for nearly two years. In this time however, he befriended several women who helped feed his desire for literature, poetry, and his passion for writing. He slowly became fluent and found an empowerment in his new found voice.

Despite the constant experiences of bitterness around him, the empowering writing Bulosan depicts is one of overcoming intense hardships through the acknowledgement of individuality. Bulosan found his voice and his inner strength through the art of writing about his personal experience and on behalf of his fellow working Filipinos. Through this, he became empowered to reveal the bitter truth of America's past to remind all readers of different backgrounds and beliefs that the process of overcoming great adversity is involved through the act of finding one's voice and using it. 


\section{Qualifications of the Investigator and Project Beginnings}

There are several mismatched, coherent reasons why I feel qualified for this creative project. In terms of skillset, I have been playing guitar for almost ten years, and singing for nearly half of this time. I have considered myself a folk singer since entering college, and having won a Filipino American singer-songwriter contest in 2012 here in Portland, Oregon. I won a whopping \$200, which is $\$ 200$ more than most folk-singers my age tend to make. Please excuse my terrible humor, though I must admit it is essential to have some type of humor when you dedicate this much time into music, an industry I joke is often a "non-profit organization." I've been writing songs since I was thirteen, and I was very eager to practice performing once attending Portland State University and finally getting to live in the "big city" (compared to rural Forest Grove, Oregon.)

Being an only-child, and growing up in a small farm town community that did not contain much Asian culture (I was considered one of less than ten Asian American students in my graduating class of 500), I have struggled off and on with coming to terms with my Filipino American identity. Most of my friends considered me to be white, yet avoided conversing on deep diversity issues that I had seen around my whole life. My mother was born and raised in Batangas, Philippines, and had met my American father in Hong-Kong after sending letters across continents through a Christian pen-pal service. They married and moved to Stockton, California where I was born.

I did not think much about race growing up, until after my first year of schooling in which my parents had decided to move to the Philippines, permanently, for me to further grow 
up. Within one year of education in the Philippines, I became fluent in Tagalog, and became hyper aware of my "differentness" as I always had friends and family pointing and poking at my pale white skin, and “caucasian” looking eyes. I wasn't sure how to make sense of it, but it led me to become an easily irritable and confused child, as you can get a taste of from this picture depicted, here:

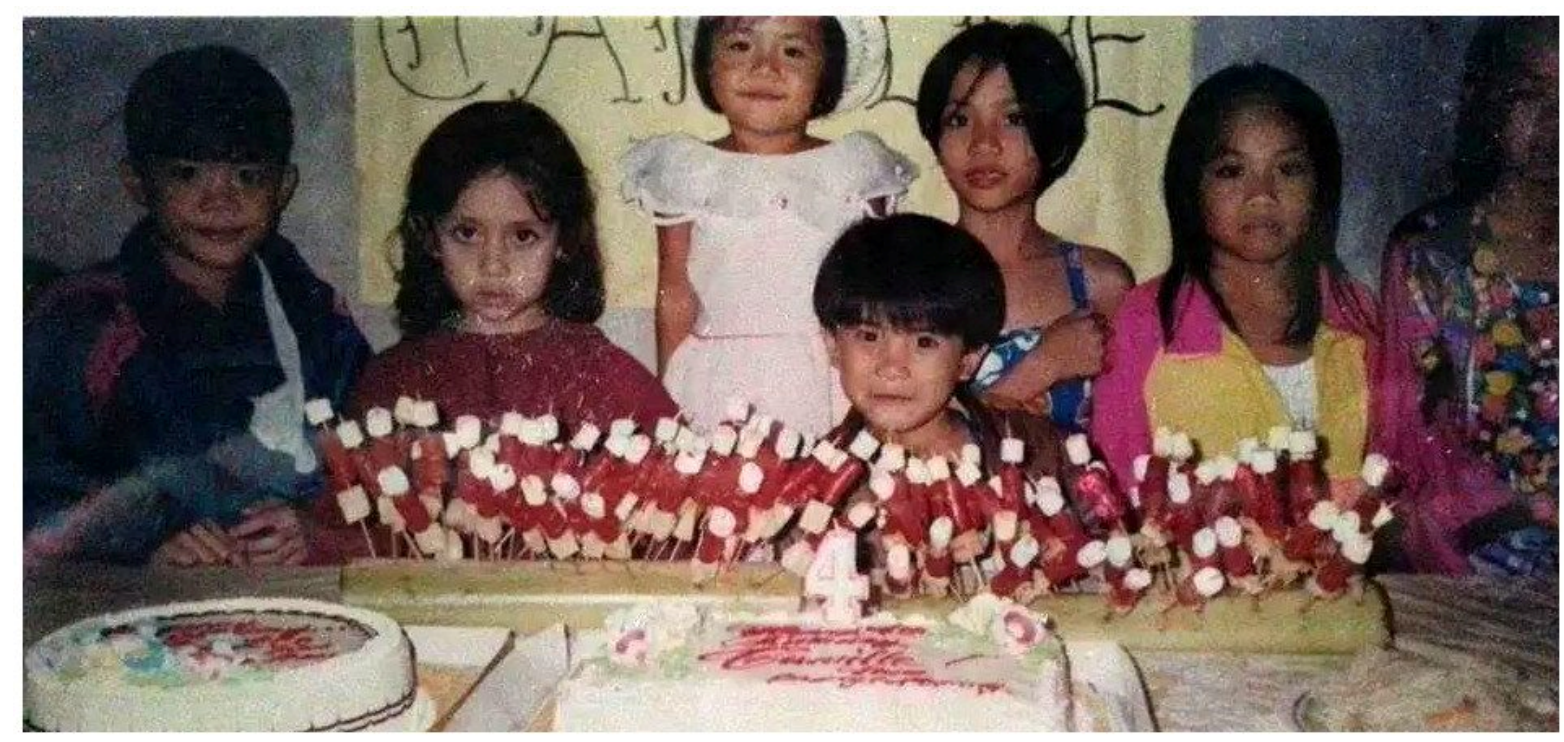

All I had simply wanted was to fit in. My mother forced my cousins at first to not speak to me in English, in hopes I would learn Tagalog quickly, and I was very lonely upon arriving to the Philippines. However, by the time I had finally become fluent, my Dad had lost his job in the stock market (there were many power outages due to monsoon season, leaving him unable to use the computer for many days on end) in which we had to move back to America with my father's parents in North Plains, Oregon. From age seven up, I grew up in a small farm town community, or suburbia, where I had few opportunities to become in touch with my Filipino identity as I did while in the Philippines. 
When arriving at Portland State University, I immediately leapt into the Filipino community, becoming the treasurer of Kaibigan, the Filipino club on campus. And having moved to a bigger city, music continued to grow as my internal outlet. Since the age of eleven I began playing guitar, but by age eighteen I was actively performing in venues across Portland such as the Blue Monk, Savoy Tavern, Backspace, the Waypost, and Valentine's (some of which have closed down now.) Having studied abroad in Prague last winter, I began an international tour, performing briefly on a Czech music television station called "Balcony TV Prague." In the summer I dove into the folk scene of Ireland, performing at some of the most welcoming venues such as Whelan's Live, the Ruby Sessions, the Mezz, the Bleeding Horse Pub, and the Black Sheep Sessions. I became in touch with a great videographer while there who helped make me a short music video in St. Stephen's Green, despite only being in Ireland for about two weeks.

Today music is still my ultimate outlet, but despite the comfort I find in songwriting, I am still trying to grasp how to make sense of being a mixed race American. Through my travelling, I still haven't found a place where I completely belong. However, taking Professor Lo's Asian American literature class had been almost therapeutic to me. Having the opportunity to read about the struggle of first generation Asian Americans to assimilate, and the identity crises behind the second generation's struggle to find their identity between the two generations, amongst other salient issues, was inspiring and uplifting. In fact, every author and character in some way has described the plight and predicament of trying to be heard; it gave me such inspiration and hope that I have never felt before, as despite being of mixed race in the $21^{\text {st }}$ century, I still struggle immensely with finding my voice. Being one of the few Asian students in high school, I was stereotyped as quiet, kind, and hardworking; but I was crippled by social anxiety for so long in regards to speaking for myself. It has taken me a long time to come to 
terms with my voice, which feels most powerful and strong when performing. But today I still grapple with the concept of "identity." The Asian American literature class helped bring new meaning to my identity, as it made me realize that all this time I have been trying to find comfort by classifying myself into a box instead of making sense of my own. Individuality in itself is freedom; individuality is voice.

Reading these novels had already led me to such influence in my song lyrics, I could not help but want to share these stories and ideas within the Portland community. In the process of writing, recording, and singing, I want this contribution of voice to be a metaphor of the freedom behind making sense of one's identity, along with being an outlet for those who have yet to experience reading ethnic bodies of literature. Highlighting these issues and genre of writing will influence varying communities; those who are unaware of it, and those who want it to be further known. Together voices across the spectrum can be heard and shared, and I see this impact as significant, however big or small it may be.

\section{Songwriting Voice and Methods}

Having songwriting being a physical embodiment of "voice," it became a delicate adjustment incorporating these ideals through the form of song. Delicate meaning, I had wanted to be respectful, accurate, and attentive to Bulosan's life experiences through song, while simultaneously being able to add my emotions as a songwriter and Filipino American. I wanted every song to be balanced and interlaced, and did my best to find harmony between these factors. I found a new challenge in completing this project; balancing three mutually intersecting roles of researcher, musician, and Filipino American citizen. All roles flowed into each other, for as a researcher it was my aim to find the themes I best wanted to represent through song, and as a musician I aimed to find a way to portray these themes in an emotional and vulnerable way. My 
identity and voice was tied into the process, as it helped me find the emotional appeal in analyzing Bulosan's words, along with matching them with music and words of my own. With a background in songwriting, I used my roots of American folk influences to help me portray Bulosan's experiences in a relatable way so that larger audiences to experience these ideals. Though folk music in itself is incredibly difficult to define due to conflicting historical views, I interpret folk music as the influences I've come across my life, such as through the roots of Appalachian folk music. I had ceased to mention in my qualifications section that I had also taken bluegrass guitar lessons while living in Forest Grove, which greatly influenced my way of interpreting music. This is how I came across the Carter family, who are commonly known as authentic Appalachian folk musicians in the $20^{\text {th }}$ century (Gold, 2006). However, Appalachian folk includes many European and African influences as it refers to music produced from the Eastern side of the United States extending from Maine to Georgia. It involved influences over centuries and centuries of immigration, which in its growth collected tunes from English ballads, Celtic dance tunes, and African-American blues from the Deep South, along with many others. The main root I see that penetrates these varying tunes, is an innate passion to portray one's story.

The popular form of how I interpreted folk music however, was through the folk revival movement of the 60s where I began to fall in love with the likes of Bob Dylan, Joan Baez, Pete Seeger, Joni Mitchell, Simon \& Garfunkel, and many, many others. I bring these names up, as many of these artists became popularly known for their activist writings which were able to portray a story from past or present, embody a situation, and share it to the world in the form of song. I too wanted to attempt this in the creative process, such as through Dylan's song "The Lonesome Death of Hattie Carrol," a famous folk tune depicting a heinous murder of a 51-year- 
old waitress by a man named William Zanzinger who had only spent six months in a county jail for his crime. His elegant description of a true event was backed up by emotive guitar and harmonica, captivating audiences around the world.

Folk music has often been known for being able to personify vivid experiences and making them more applicable to being shared. It is a unique form of music in itself as it often aims to displace the musician and embody someone else in order to portray a greater message, most often relatable to present day. With the knowledge of Appalachian folk descending form generations of European immigrants, I found this genre of music as an interesting and sufficient form of writing towards portraying Bulosan's experiences.

I am continually inspired by how much of folk music intertwines with writing, and this project seemed an excellent fit for such music, as I have yet to hear folk music embodying the Filipino American experience, let alone during such a bitter time as the Great Depression. From reading Bulosan's story, I felt drawn and empowered by his use of voice to make a difference in his community, despite the ongoing hardship. It was an exciting challenge to display themes I believed were important and applicable towards the human experience.

In reading Bulosan's personal history, I kept a journal with me to track down important themes and motifs I noticed throughout the novel. Though at first I had read the text to grasp main ideas regarding his experience, my second reading was in order to track vivid imagery and subtle allusions that further inspired the development of the songs I produced. Once I found my major themes, I made a list and began creating guitar riffs to match the ideals I wanted to portray. A theory involving musical emotions by psychologist Juslin Patrik of Uppsala University states that one possible explanation to the widely appreciated art of music is due to "the deep emotional effect music has on people" (p. 383). This for me was the fun part, 
experimenting with timbre, tone, loudness, tempo, in order to create the desired emotion to match the words on paper. A unique strength through using the medium of song is the innate ability to tap into a listeners emotions, reaching a level of artistic expression that can directly interact with a listener (Patrik, 1997).

In writing the songs, many of the lyrics were from my discoveries of journaling. All three songs involve bits of "found poetry" in which I took small phrases from the text and placed them in a certain order to create a desired meaning. However, I ended with around seven half-written songs throughout this creative process, but only three I believe gave justice to what I believed helped embody Bulosan's work. These themes being the numbness of silence, hope in individuality, and the acceptance of saying farewell. The songs listed below were carefully constructed through both Bulosan's words and mine, in hopes towards creating a desired effect of consciousness regarding these topics, though it is your role as listener develop meanings that relate to your own experience. Take what you will, and it is my role as musician to simply hope you enjoy. 


\section{Tired of Being Quiet}

We don't talk about the distance, we don't talk about the hunger.

Perhaps since we don't talk, they cannot tell we're going under.

Perhaps that we've been fearful

of not doing what we're told.

Oh it's easy being silent, but it ain't easy being alone.

In a land where I'm a stranger,

Is a land where I am numb

I cross the street shadows to hope the whole world won't find out.

My rights are still translucent, as a sharp wind in the cold.

Oh it's easy being quiet, but it ain't easy being alone.

I learned that poverty is normal, I learned the language hurts my tongue. I learned the jobs are scarce like cutlery and sharp as hunger to my stomach.

My bravery still nameless,

in expressionless expression.

Oh it's being quiet,

But it don't leave much room for questions.

When can we live to love forgiveness?

When can my brothers know their names?

Will we ever find the balance of sharing land in the same place?

I feel the new world slowly blooming

As the old one starts to mold,

America the distant,

America the cold.

So grab your friends and brothers,

Tell them you are done.

The war's gone long without us

Using the ammo of our tongues.

I see justice in each pea pod,

And every hand that's gone to feed it.

Because I'm tired of being quiet.

Yes I am tired of being silent,

Because my soul is yet defeated. 


\section{Another God}

The perfumed daughters, the sleek haired sons.

The tiny yellow plains, are in my heart.

We ran the fields, until our legs turned hard

The burnished earth, upturning roots and bark

This is our land, our churning hands to breathe unto the earth, and family.

I was a child once, though never fully.

I saw my family work for years for brother's schooling.

My father's land, that he had born and fed, another field my bleedings hands forget .

Another life, in which I must move on

Another land, another God.

The traveling manhood in the night.

They take our voices boys, they'll never take our silence.

There is a pride sown in the land.

Yes I was born here, and I must come once again.

I see the ghost, which haunts me letting go to bear the guilt, of fleeing my old home

This is a life, that I am scared to leave,

But so it's mine, and I proceed.

It is not simple, to ignore violence.

Poverty sharpens all its teeth, and leaves with silence

This land held hunger, I simply can't forget

I've seen my brothers, re-live a dozen deaths

Another life, another land to leave

I fear for future, I fear for me.

Goodbye the silk moon. Goodbye the sweet dew

Goodbye the sunshine in my eyes as father wept through

"Even if you steal, even if you kill don't go

Even you lie, promise you won't come home"

Another life, another port to go,

Another man, another land.

Another shore, another God.

Another body, another God. 


\section{Individual Soul}

Oh it's hard here to live, but even harder to die.

I've grown great yellow lines under each tired eye.

Why do men live so thoughtlessly? Life cannot be borrowed

My hunger for life grows, but so does my sorrow.

Oh I live on this block, little Hope Street you see

Filled with prostitutes and gambling on each shattered knee

I can swindle my money as long as I please

The cops drop as often, as fresh fruit from the trees.

It's a hard life, a short life, but my eyes are bold.

I have worked far too hard to let history mold

It's easy to act like our lives go undivided,

But I'll write for the workers and write for the silent

Oh my heart yes my heart beating firm against my chest

Though I'm missing several ribs, it still murmurs softly this:

"You are bright as the moonlight,

In the individual's spirit, the individual soul." 


\section{Findings from the Experience}

Through the journey of this creative thesis, I was surprised at how emotional it became intersecting the three roles of researcher, musician, and Filipino American. I found that each role fueled another in each layered cycle, and the songs would not have been completed without the other. To provide an example for context, I found from my close reading that Bulosan uses great lively, vivid imagery when he is relating to his experiences with nature. In this realization, I wanted to capture as a researcher these adjectives in my journal, tracking words and phrases relating to nature for future use as found poetry. As a musician, I became drawn to how he spoke of the moon, as he had many night metaphors that related to freedom and individuality. In the second song, "Another God," I trace back imagery of his childhood in Mangusmana as he describes the evening and morning with "silk moon" and "sweet dew." I then noticed how Bulosan's attunement towards nature became prominent in the novel at times he knew he was saying goodbye to an individual or to a land, and that his appreciation and longing flows into his love of nature. This finding reminded me how music that is often attuned to heartbreak focuses on the tiny details of what has become dearly missed. The music was aimed at matching this attention to detail through soft fingerpicking along with the sliding into and out of a major key to represent a fleeting feeling. During this project, I found through my emotional connection with being Filipino American, my identity in itself was helpful in combining these literary and musical findings with greater emotions behind this literary pattern. Bulosan's writings reminded me of these tiny details of heartbreak, which is why "Another God" is an embodiment of nature to represent a theme of longing behind our many farewells we must face during a lifetime.

As a songwriter, it is not nearly as fun sharing the behind-the-scenes-meaning of a song for the listener, so it is an artistic wish to withhold information behind the created imagery of the 
songs "Tired of Being Quiet" and "Individual Soul," as it is easy to guess the formula after my previous hints. Instead, I would like to speak more on the emotional connection I found towards this project, as it took on a new level of learning I had not quite experienced before. This project was interlaced with emotional connection towards the writings: both Bulosan's and my own. These emotions kept me present, aware, and attuned to what images were coming into my mind, and which images were to come out. I say this, because it was a prominent realization to see what type of work can be created when one becomes an active emotional listener. In my personal opinion, I believe this is an important difference between a student becoming engaged within an education system or not, and it was great pleasure to be able to take hold of my education through writing within a subject I was emotionally connected to. This project helped me feel more in touch with my Filipino American heritage, and sparked many more fires towards becoming a more conscious musician and Filipino American.

The musical comfort zone I was so used to in songwriting has been stretched, knowing now that I can embody different perspectives, along with using different approaches towards research. Though in the end, I wish I held an album's worth of songs for this project, I feel that this form of songwriting is a technique that can be honed in on through the years, and I have created a worthy product of respect with the level of experience I am currently at in songwriting. Now that the product is created, I enter the next realm of finding communities that can engage with these songs, and who may find great joy in listening. Working with Kaibigan, the Filipino American club on campus, we will have a workshop set up for early July in which I will be debriefing and performing these songs with the Portland Filipino American community. With a dream of one day becoming a simultaneous musician and educator, it is an understatement to say how excited I am to share Bulosan's voice along with my own. 


\section{Conclusions and Future Prospects}

My dear friend Peter Ryan owns a recording set-up known as “Tiny House Studio.” It was a very vulnerable experience realizing how far these songs have developed since beginning this project. I immediately became shy when showing these songs to someone for the first time. Will this message be reached in the right way? And how can one measure success in a creative project?

I still remember the first moment when I pulled out my guitar hesitantly after entering his house. I took a deep breath. I remembered that these songs are a reincarnation of "voice" itself, and hoped I could give justice to Bulosan's experience. We lit a candle before recording, and spoke of our intentions. I played Peter the first song, "Tired of Being Quiet.” A weird emotion took hold of the room, and when I finished, I saw tears in his eyes. From my experience as a songwriter, I felt an overwhelming wave of peace. It is a great honor to be a perpetuator of emotion, and it moved me to see that my words and months of intimate work had reached someone. He was the first to hear these songs, and it had me contemplate, that perhaps I have really done my job here.

I'm excited to share these pieces with Kaibigan, the Filipino community on campus next month, featuring a workshop on the emerging "voice" within Bulosan's novel. This project for me was an intersection of the three balances previously stated: researcher, musician, and Filipino American. In this I had the opportunity to learn more about a prolific writer of the $20^{\text {th }}$ century who directly empowered a culture I associate with deeply, closely analyze a text in order to create associated meaning through song, and practice how to capture themes through music that can be experienced through a listener in an emotional way. It has been a great challenge being 
the middle man through each of these roles, but in the end I found my voice merging with many influences in which I am proud to share.

Now looking back, I am realizing this project planted into my consciousness during a vulnerable place last fall, as an Asian American literature class influenced me to rediscover and define my relations to my Filipino American identity. I started writing songs out of anxiousness, loneliness, but felt constantly rejuvenated by the theme of the "emerging voice" through each novel we finished. Bulosan, among many other influential Asian American writers, were able to rise above their misfortunes through diving straight into their experiences and sharing it with the world. It is a very vulnerable place to be in, but in this process, many lives have been continuously shaped and inspired. For this I am thankful, along with the opportunity of contributing to this newfound voice and vulnerability.

To end with Bulosan's words:

"Full of loneliness and love, I began to write." (p. 289). 


\section{References}

Bulosan, C. (1946). America is in the heart: A personal history. Seattle: Harcourt, Brace and Company.

Gold, J., \& Revill, G. (2006). Gathering the voices of the people? Cecil Sharp, cultural hybridity, and the folk music of Appalachia. Geo Journal, 55-66.

Iijima, C. (1997). The Era of We-Construction: Reclaiming the Politics of Asian Pacific American Identity and Reflections on the Critique of the Black/White Paradigm, 29 Columbia Human Rights Law Review, 68-89.

Juslin, P. (1997) Emotional Communication in Music Performance: A Functionalist Perspective and Some Data. Music Perception: An Interdisciplinary Journal Vol. 14, No. 4, 383-418.

Takaki, R. (1989). Strangers from a different shore: A history of Asian Americans. Boston: Little, Brown. 